SHIROKOGORORF, S. M.

1935 Psychomental complex of the Tungus. London, Kegan Paul.

SPENCE, LEWIS

n.d. The magic and mysteries of Mexico. London, Rider.

SPIER, LESLIE

1935 The prophet dance of the northwest and its derivatives: the source of the ghost dance. Menasha, Wisconsin, George Banta Publishing Co.

StEWARD, JULIAN $\mathrm{H}$.

1933 Ethnography of the Owens Valley Paiute. University of California Publications in American Archaeology and Ethnology 33.

STEWART, KENNETH M.

S46 Spirit possession in native America. Southwestern Journal of Anthropology 2:323-39.

SWANTON, J. R.

1905 The Faida Publications of the Jesup North Pacific Expedition 8.

132 Washington, D. C., Bureau of American Ethnology.

THaLBTrZer, W.

the East Greenland Eskimo. In Source Book in Anthropology, ed. A. L. Kroeber and T. T. Waterman. New York, Harcourt Brace.

Schubinow, Georg

1914 Beiträge zum psychologischen verständnis des Sibirischen zauberers. Halle. 1914 Beiträ

1920 (1871) Primitive culture. 4th ed. London, John Murray.

TyrreIL, G. N. M.

1947 The personality of man. London, Penguin Books.

1947 The personality of mas

VIRGIL (PUBLITS VERGIIUS MARo) 1953 The Aenei

1939 Religion in primitive society. New York, F. S. Crofts.

WELMERS, WILLIAM E.

1949 Secret medicines, magic, and rites of the Kpelle tribe in Liberia. The Southwestern Journal of Anthropology 5:208-43.

WIKKEN, G. A.

1887 Het shamanisme bij de volken van den Indischen archipel. Bijdragen tot de taallanden volkenkunde van nederlandsch-Indie, Ser. 2 . The Hague.

\section{Associations in Fiji Indian Rural Society}

ADRIAN C. MAYER

Australian National University

NDIANS who have settled in the rural areas of the Colony of Fiji have two 1 principles behind the management of their associations. On the one hand, there is the idea of decisions unanimously arrived at by all parties concerned or by all the men acting as arbitrators and leaders. On the other hand, there is the principle of open voting, in which the decision of a majority is adopted. It is clear that these two methods of procedure will often conflict if applied to the same association. A compromise may be possible in communities whose members have a common background and interest and a tradition of strong leadership, for differences may then remain subordinate to an over-all sense of solidarity and a trust in accepted leaders. But the varied cultural and social segmentation of Fiji Indian society, and the lack of any pattern of accepted authority, make for wide differences in the rural settlements. Frequently, then, the unanimity which is formally shown by the open vote of all assembled, or of the chosen arbitrators, is no more than the result of pressure used by more powerful groups and individuals. The attempt to have such overt unanimity may, in these circumstances, result in deeper divisions than if there were an open recognition of differences. For if an insistence on formally unanimous action precludes the overt expression of minority opinion through a vote, the secession of these minorities may take place, the "unanimity" then becoming a factor of division. Further, an association which acts on the assumption that such an overt unity is real will sooner or later divide if it undertakes work (such as the arbitration of disputes) which needs a real interdependence and unity.

The analysis of these principles, though made for a single area, is of wider interest, particularly to students of India. For the principle of unanimity plays a large part in the operations of the panchayat, the traditional arbitrative and administrative council in India, which also has an important place in Fiji Indian life. Conditions in Fiji may be found relevant to those in India, where the processes of panchayat unanimity and the new democratic majority rule increasingly confront one another. For there is, on the one hand, the development of rural panchayats based on universal suffrage and the voting of decisions and, on the other, the plea of people such as Acharya Vinoba Bhave for unanimous, rather than majority, decisions.

The paper embodies material gathered during a year's stay in Fiji in 1950-51. During this period three settlements were studied in detail, each of which appeared typical of Fiji Indian rural areas. All were of average size, containing some 500 people in an area about one and a half miles square, and each was within five to fifteen miles of a small market town. They contained representatives of all the major cultural groups to be noted below, and farming followed the broad variations of crops found elsewhere. 
Three associations were found in these settlements: the cane-cutting gang, The Settlement Association. In no settlement did all three exist, but there were one or two in each area and they are general throughout the rural Fiji Indian settlements.

\section{THE BACKGROUND}

Indians first came to Fiji in 1879. They were brought under the auspices of the Governments of India and Fiji for terms of indentured work in the of the Governments of India and This system continued until 1916, up to that time 62,837 Indians having come to $\mathrm{Fiji}, 24,655$ of these being repatriated time 62,837 Indians having come to $F 1 j, 24,65$ of these being repatriated under terms of the contract (Derrick 1951:138). Since then, the Indian population has had a rapid natural increase, the average annual net immigration being no more than a few hundreds. By 1951 the community numbered 143,332, or 47.5 per cent of the Colony's total population; of the balance, Fijians numbered 132,889, and Europeans and others, 25,738 (Colonial Reports, 1953:10). With a few exceptions Indians and Fijians do not live in the same rural settlements or intermarry, and so, for the purposes of this paper, only Indians need be considered.

After their contract work in the plantations had ended, Indians were free to settle wherever they could lease land from its Fijian owners. An account has been given elsewhere (Mayer 1953:182-85) of the pattern of settlement which emerged. Two features are relevant here. The first is that the settlements consisted of homesteads settled piecemeal, with houses dispersed over the entire settlement area. This has meant an obvious physical difficulty in organizing associations, whose members may be reluctant to walk a mile or more for a meeting. It has also been a factor in the low social articulation of the settleme decisions of some of the ment, which has made for diffich

The second fact to note is the considerable cultural diversity represented. Recruitment under the indenture system occurred first in North India; after Recruitment under the indenture system occured Telegu areas of 1900 , however, most immigrants came from the Tamil and Telegu are Madras State. There are no statistics available of the birthplaces of immigrants out Coulter estimated in 1935 that 64 per cent of the Fiji Indian population stemmed from the North, 29 per cent from the South, and 7 per cent from ther areas (1942:81). Three main cultural groups can be seen in our settlements, based partly on area of origin and partly on socioreligious variations (see Table 1). They are Hindus from North India, Hindus from the South, and Muslims (almost all of whom are from the North). These groups are almost entirely endogamous in rural areas. Within the two former there are castes having varying degrees of endogamy, and the Northern Hindu group also contain contains men of the obtaining in the Fiji in the three settlements corresp

Differences between these groups (the small Sikh and Christian groups not being considered separately here) lie largely in the ritual and kinship spheres; 
94 per cent of the land under cane, Fijians 3 per cent, and the Colonial Sugar Refining Company (CSR) farmed the remaining 3 per cent, leasing out most of its considerable holdings to Indian tenants (Shephard 1945:42); these proportions cannot have changed greatly in recent years.

The sowing and cultivation of cane is performed by each farmer on his own block of between 10 and 12 acres. But cutting the cane is highly organized by the CSR to insure a steady flow of suitable cane to its five mills, the only mills the CSR to in in the first, called a Memorandum of Purchase, settles the ecifies that the cane "is to be given when and where directed (st cane "is to be given when and where directed by the Company on its main line loaded on trucks ... or in punts ..." (clause 7 of the 1940 Memorandum). These agreements are usually made for en growers then form themselves into a partnership, ten years at a time. "The signing a Grower's Harvesting Agreement each year (a) before the cutting season starts. Each gang mainly contains the men of one settlement, others only coming in when the neighboring settlements have too (he average, a gang will harvest about 5,000 tons (t) 450 acres of land under cane, not all of the land being harvested each year.

As to the gang's operation, every farmer must have one representative in the gang for every estimated 100 tons of his cane (or, sometimes, for every 6 . Some men cut the cane, others lay portable line from the en the cane, others lay portable lise from the permanent railway and haul trucks to the cutters. One man acts as waterbearer, and one of the gang is elected to be sirdar in charge of operations. Above the gang there is a European field officer appointed by the CSR. Among his other duties, he acts as liaison between the gang sirdar and the officials at the for the trucks to be sent to the gang and advises his superiors mill. He arranges foris on the progress of the harvest. Besides this, he supervis ther having execuoperations and discusses its problems with the sirdar, the latter tive responsibility.

in farmer's field the cutting and haulage harvests the cane in a farmer charges are debited to his account with the CSR and are subtracted from the sum he later receives for his cane. These costs are noted by the sirdar, and the farmer or his alternate then has to earn an equal amount from his work, an in the gang. Everyone therefore puts into the gang, through bis wor those amount equal to that which he receives when the gang cuts his cane. For those whose harvest expenses are high, their land being far from the permanent railway, more work is needed to level out these two heads. Often the balance is 列 a wit of work and then have everyone complete a cergangs prefer to define a unit of winciple of equality of contribution and benefit tain number of units; but

is everywhere the same.

The operations of the gang may provide grounds for disputes or may be ere pretexts for quarrels by men who are already at loggerheads seized upon as pretexts for quarrels by men some other affair. On the whole, however, they appear to give rise only to minor differences, usually between individuals. It is the election of the sirdar that provides the major occasion for divisions of the gang, in which these smaller disputes may play a part.

Open elections of the sirdar, though a formal part of the machinery of appointment, are disliked. As one man put it, "elections are bad, for they only create opposing parties." Another man had these views:

People in a gang will always form parties. A sirdar will usually favor his friends by giving them portable line to cut their cane at the most favorable time and so forth [this is not quite true, since the field officer makes up the rota of cutting, but many people believe that the sirdar controls this list-especially if they are against the sirdar]. A party will rise against him at the next election. Both sides will talk to all farmers before the election, and if the result appears close, within a vote or two, there may be voting But if a group realizes that it is in a minority, its members will give in before the election, and the candidate of the largest party will be elected unanimously without a vote, because others will be discriminated against in the next season if they openly vote against the sirdar.

It therefore often happens that there is no election for the post of sirdar whatever disagreements are latent in the gang and however strong the jealousies may be among the disappointed aspirants--the only vote recorded in some 20 elections was 14 votes to 11 , close enough for each party to hope for victory.

The fact that elections are unanimous, we see, does not prevent strenuous canvasing before the event or high feelings after it. This is the case especially if the election is made part of a more general contest between factions in the settlement. In one gang, for example, there appears to have been general agreement over the sirdar for many years. More recently, however, factions have arisen, taking the form of a division into a majority of orthodox Northerners, Southerners, and some Muslims, and a minority of Arya Samaj Northerners and other Muslims. The subjects of difference have not been primarily the capabilities of the sirdar but have concerned local subjects of dispute, and also policies pursued by two Fiji-wide cane growers' unions, each supported by a different faction. These unions, in turn, are part of the Fiji political scene, since rival members and candidates for the Legislative Council of the Colony actively support them. Their organization is on a District-wide, not a settlement, level, and most of their leaders are townsmen. They cannot, therefore, be classed as rural associations of the kind we are considering here, nor do they have explicit control over the gang. But their policies may indirectly affect the gang's operation by providing bases for divisions and pre-election tests of strength, and they have on occasion directly affected the gang's work with a successful appeal to strike.

In another settlement the sirdar's election has been tied to factionalism within a large kin-group, expressed partly in a struggle to control the gang by having a sirdar friendly to the winning faction. But only a few men of other kin- and cultural groups have been firm members of either faction. The rest of the gang has supported one or other of the candidates offered, according to 

and also with the candidates themselves. A man might trom whom he had hopes support a candidate to whom he was indebted, on small to vote of some favor. Again, 'the lleader of a small cultural group, too' support until him in without outside help, would hold off his and his kinsmens and would then it was clear that there would be no compromise candide atter terms. This hrow his support behind the man with whom he was on the bett terment changing support accounts in part for the number of sirdars in this settlement 10 in 12 years-and their varied cultural group membership: 2 have been Muslims, 5 Southerners, and 3 Northerners.

\section{THE SCHOOL COMMITTEE}

There are three main types of school for Indians in Fiji. Some are operated Tepartment, and others are under private FijiDut about two-thirds of the wide organizations, like the Methodist Mission. But about. Each committee is reponsible for the upkeep of buildings and pays 25 per cent of the teach salaries from fees collected from the parents. The Education Department pays the remaining 75 per cent and may make grants for construction work. The teachers are civil servants, directly under the control of the Department. There is an Education Officer and an Organizing Teacher ard, catering for The committee schools are of primary standard, cateng ingers is taught orally from the beginning,

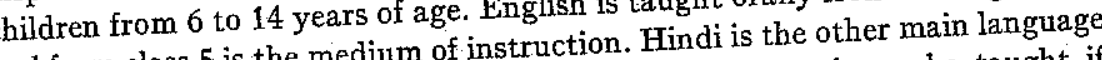
and from class 5 is the me taught if though any regional language, such as Tamil or Gues.

enough parents desire it and the committee appry within three miles of

Because official policy is to have no country schools within the settlement, each other, establishments usually cater to an area large Usually the settlement each on the committee. men from several settlements being on which most pupils come, has more repin which the school stands, and from which most pupils com that body variesresentation on, and interest in, the committee. The size thittee of 27 , of whom one school of about 200 pupils was operated by a committee of 27 , of witions 7 to 10 composed a working group of regular attender deputies. Upon these are held by a Manager, Secretary, Treasurer, and their deputies.

men rests the major responsibility for the school's administration.

The election of the school committee officers tends to follow those who pattern as in the gang elections, there being unanimous choice of those who have succeeded in the pre-election canvass. Similarly, issues policy, or to faccan be related to internal differences in the committee over policy, or to factional activity in the settlement, and feeling between cultural or for example, The protists in a discussion over the best way to collect fees, for exam The protagonists a discusion over other matters in the settlement. Further, were at the same time opposed over other matters the committee, differences where men from several settlements take part in the committee, diffeen people may have a territorial basis. Thus, one committee was divided its. locality and f settlements, each group wishing the school to be in its locality and

supporting candidates from its settlement. 
bers at the weddings of people too poor to hold a feast of minimum proportions, and will organize activities at the major festivals (e.g., Mayer 1952) These activities are aided, or tacitly approved of, by all members of the Association and even by those who do not belong. The aspect which most interests us here is that of arbitration made, it is said, to save money otherwise spent on litigation. Here the Association has taken over functions performed the two bodies by the panchayat in areas where no Associations exist. Since the two bodies have the same aim, though different procedures, we can examine them at the same time.

First, the panchayat (group of five) is theoretically said to be formed by the selection of two men by each disputant, these then choosing the "head" of the five men. They hear the evidence presented by both sides, confer, and hand down their unanimous decision. In practice, however, there need not be five men for matters of importance there may be more, and in small disputes one or two men, known to be experienced and impartial, are said to be enough. All the panchayats recorded were $a d$ hoc bodies, called to hear a specific dispute, All the panchayats recorditorial or cultural basis.

Fourteen instances of panchayats were noted, eleven of them between men f fifferent kin-groups, three within a kin-group. Of these, four can be classified of differ in another a man was accused of neglect in allowing a bullock to be injured. Three panchayats concerned cultural group friction-some Muslims, for example, killed a cow near a Hindu house. Two meetings were held over cases he remainder (save for two cases to be noted below) were about of assault, and the remainder (save for two cases to be noted below woint household. land boundaries, a quarrel over a woman, and a quarrel in a joint household. The panchayats therefore deal with a wide variety of cases. In all these instances the panchayat punished by levying a fine or demanding an apology, and its unanimous decision was accepted by the loser. Though the panchayat is said to be unable to invoke sanctions to-enforce its decisions, there is no doubt a fear of general disapproval if it is not obeyed. Moreover, agreement on the verdict is reached by the representatives of both sides to the dispute, on the latter can scarcely disavow the decision of their own nominees.

Two cases were noted, however, where the panchayat had ostracized an The first case, the man, who had committed incest, was little by little visited by those to whom social or economic contact brought benefits worth disregard of the panchayat decision. In the other case, the boycott was applied to a storekeeper, who did not accept the decision and compelled his debtors to continue their thate with hextreme penalty of ostracism is inoperable by panchayats unless accepted by its important that in both cases the accused was on one side, and the panchayat was said to be "acting for" the entire settlement on the other. The failure of this type of panchaing cused of causing splits by trying to speak for the whole settlement.
It must be stressed, of course, that the acceptance of any panchayat ruling does not mean that the dispute is thereby finally settled. The contestant who thinks he is the loser may try to revenge himself later, and factions may then arise. If the loser is dissatisfied with the decision, moreover, he can take his case to court. The panchayat may only stop the quarrels of the moment, though it may be more successful than this. A major aspect of importance is the unanimous nature of the panchayat decision. It was said that to be a good member of a panchayat a man should have a "hot" temperament, as well as qualifications of literacy and an experience of authority in other matters (e.g., a sirdar's post). The hot temperament alone is not enough, but it is needed in cases where the opinion of the panchayat is divided and where someone is required to speak up fearlessly and persuade a unanimous decision.

Take now the Settlement Association and its attempts to arbitrate. As noted, the Association aims to serve the entire locality; but Fiji Indian settlements have hitherto had no such single controlling body. The areas were settled with persons of great heterogeneity of background, as indicated, and people have co-operated only when it was in their interests to do so. The Settlement Association wishes, however, to have unified action even when it may not be immediately beneficial to some, so long as it is regarded by its executives to be of service to the community as a whole.

In several cases the decisions made by the Association have not been accepted by everyone, and cleavages in the settlement have resulted. These are of two types. First, there is what can be called the opposition; here members of the two sides have no economic or social intercourse. Second, divisions may occur; in this case the people on both sides talk to each other and may attend each others' social functions if the division is not too serious-but they cooperate only partially or not at all in Association matters.

As an example of the first type of split, an individual in a settlement disagreed with the officers of the Settlement Association over their condemnation of some of his activities; he left the Association, not attending meetings or paying dues. The leaders of the Association decided that its members should boycott the man because he had repudiated their judgment, over which they felt themselves justified. People who lived far from the man obeyed this ruling, since contacts with him mattered little to them. But his nearer neighbors feared that a boycott would bring out many petty quarrels with him over straying cattle and boundary lines. They considered it was more important to be on good terms with a neighbor than to censure him for actions which did not directly concern them. They therefore continued to associate with the man and were in turn boycotted by the Association, and an opposition ensued.

The Association was criticized by some of its members, for they maintained that it had overreached its authority and proper function. The appropriate objects of the Association, they said, were those of a ritual and social nature already mentioned. As regards arbitration it should, at most, hold itself ready to give its good offices to those who wished its help, and only then lay down a judgment. In fact, they wished it to behave in the same way as the panchayat, 
only acting when both parties involved agreed to attend it and heed its dhe personal outlook of the speakers, the principle expressed differs markedly from that held by the Association's officers. These regarded the body as having a responsibility, given it by its members, in all quarrels of the settlement, whatever the wishes of the disputants.

It is significant to note that the people in the boycott mentioned above accepted their position of opposition. It would have been hard for them, had to have re-established social contact with Association members, without to some extent agreeing with the pronouncements of that ody on their case. In this the panchayat and the Association differ. An unilling in position after willing victim of a panchay as an $a d$ hoc the decision of the panchayat has, in time, faded. The panchayat, as an ad hoc body, no longer exists to enforce its sentence, the latter now depending on the support of those who believe in panchayat decisions but who may my ceptions, for personal reasons, in specific instances. But any attempt by a boycotted person to revoke the Association's decision meets with action by a permanently established body, which will eject any of its members if they do not conform. Splits within the settlement. were thus made wider by the Association than they might have been with a panchayat's decision.

Because of this degree of irrevocability, however, oppositions appear to Beldom. It is only when a dissenter can, in fact, carry on alone that he can afford openly to oppose the Association. This may be when, as in one case, can the settlement and was able to co-operate with people of a neighboring locality; or the boycotted man may co-operate with people of a nighbor self-sufficient for his labor. Though the live in an isolated homestead and be self-sufficient for his labor. Tho low, and general level of interdependence in Fiji Indian settlems a mar in preventin confined largely to economic activities, it is nevertheless a factor in preventing too many oppositions. It is also noteworthy that the recorded cases of boycot did not concern men who were members of a cane gang, nor did their children stop roing to school It is improbable that anyone could be denied Governmentsponsored education; nor would it be economically feasible for any cane farmer to risk a boycott of his crops by the gang, even if the CSR were to leave them in activities uninfluenced unharvested. Oppositions must therefore exist only in activites uninfuenced by such outside organizations. The recorded oppositions involved only a small minority of people, and the probability that boycotted people might eventually form the majority of the settlement, and thus reverse the roles, appears theoretical.

Divisions are formed when people disagree with the Association's policies and activities. Some pay no further attention to them, some join in only at 作 major ritual occasions, and yet others remain active Association members but form a recognized though covert faction of dissidents within it. Members of one or more factions may be executives of the Association, though one faction one will hold power. Each faction will try to keep its members and to enlist alone will hold power. Each faction

The Settlement Association professes to speak and act for the entire membership. And, on the face of it, it would seem that its leaders are justified, for they have been unanimously elected. But the unanimity, in fact, often masks this minority opinion. Two circumstances can bring it into the open. First, if divergence of opinion over the Association's policies can no longer remain covert, the weaker faction may withdraw from the Association so that this body can again be "united," and this will mean a division of the settlement. If dissidents do not leave the Association, elections may be postponed, as mentioned sidents do not leave the Association, elections miation may fail-"go bad," it is said. The second circumstance is when the Association arbitrates between its members and presents them with an "either-or" decision. If they do not accept the arbitration, however unwillingly, they must withdraw (again, to preserve unity) and, because they have challenged the authority of the leaders, may be boycotted and an opposition formed.

Given this need for at least overtly, if not truly, unanimous decisions, then, the Settlement Association is a body which needs certain prerequisites of unity before it can operate without splits. An over-all authority is necessary, whether supported by supernatural powers, or by lineage and caste superiority, or by supported by supernatural powers, or by lineage and caste supens are needed common agreement, or a combination of all these, and functions are needed which all people recognize as appropriate to the Association. Fiji Indian rural society, as investigated, does not possess these bases of unity. There is no generally accepted channel of authority, there are jealousies between leaders end their potential successors, and the Settlement Association is too recently and their potential successors, and the Settlement Association is too recently gious differences between cultural groups invest disputes with an added dimension of disagreement. The unity everyone desires in these permanent associations is therefore only an ideal, in spite of the unanimous vote at election time, just as the disputes nominally solved by unanimous agreement in an $a d$ hoc panchayat judgment may continue later, in different guise. But at the hoc parce there seems to be a felt need for an authoritative body and leader, perhaps partly coming from memories of traditional authority, partly from the sight of other power structures in Fiji-the Government hierarchy, the Fijian system of chiefly rule. Settlement Associations are thus started, and try to allocate this position to themselves.

\section{CONCLUSTON}

Two developments from the present situation appear possible. First, changed conditions may favor associations working under the principle of unanimity. Authority may become firmly vested in certain families or in the hands of wealthy or educated individuals; differences between cultural groups may become less marked; and better internal communication would be a further factor aiding this development. The continuing existence of the associations themselves may make for an increasingly solidified division of super- and subordination. With such bases, associations might operate with unanimous decisions. Though this unanimity might not always be a true one, in the sense 
of a genuine agreement, there would be sufficient co-operation to avoid divisions or oppositions.

Possibly, however, the future will see a lessened distrust in the existence of vocal minorities and a realization that the airing of differences can take place openly within an association without foundering or splitting it. Elections will then reflect trends of opinion which at present usually remain covert.

\section{REFERENCES CITED}

Coloniar Reports

1953 Fiji: 1951. London, H. M. Stationery Office.

COULTER, J. W.

1942 Fiji: little India of the Pacific. Chicago, University of Chicago Press.

Derrick, R. A.

1951 The Fiji Islands. Suva, Government Press.

MAYER, A. C.

A57 The Holi festival among the Indians of Fiji. Eastern Anthropologist Vr, No. 1:3-17. 1953 The organisation of Indian settlement in Fiji. Man LIII, Art. 284:182-85.

SHEPHARD, C. Y.

1945 The sugar industry of Fiji. London, H. M. Stationery Office.

\section{Double Descent and Its Correlates among the Herero of Ngamiland ${ }^{1}$}

GORDON D. 1

Universi

\section{INTRODUCTION}

RUE double or dual descent, i.e., the utilization in one society patrilineal and matrilineal principles of affiliation resulting in two systems cross-cutting each other, has been found in scattered examp. several parts of the world (Murdock 1940). Our knowledge of the vari operation of some African double descent systems has been greatly el by recent studies by British anthropologists of the "structural-fun. school, namely, those of Forde (1950) on the Yakö, of Fortes (1950) Ashanti, and of Nadel (1950) on the tribes of the Nuba Hills. The 1 and Herero, Bantu peoples of Angola and South West Africa, also ( their societies on a system of double descent. That the Herero possess : descent system has been clear for about fifty years from the reports sionaries and travelers in South West Africa (cf. Dannert 1906; Irle 19( Mbundu system has had recent treatment (Childs 1949), though ar: report (Hastings 1933) indicates that a fuller study of Mbundu social o1 tion might be made. The Mbundu and Herero systems show both mor] cal and functional similarity and are doubtless related historically ! 1952). This paper will be concerned with a description and analysis double descent system of the Herero of Ngamiland, which the author vestigated in recent field study. ${ }^{2}$ The data of the older sources were , against current custom in Ngamiland, and further investigations were 1 fill out the picture of Herero social organization and to discover change may have occurred. It is hoped that the structural-functional type of : here employed will make this study useful for comparative purpose studies should lead eventually to a general theoretical explanation of descent, if indeed one is possible.

Any subdivided society, it is self-evident, requires mechanisms to and regularize at least a certain minimum of social interaction am divisions. If the amount of interaction were to fall and remain below the level, the society would fracture into independent systems which wou thereafter to differentiate culturally. In societies segmented along lines, there will always be found to be some institutions, such as rules c marriage, economic co-operation and exchange, government, juridical a or religious participation, which operate across segments and so prev society from splintering into numerous culturally independent groups. V therefore, contrast the forces of "disjunction" which divide a socie groups, be they based on residence, economic or hereditary class, ethnic descent, or whatever, from the forces of "conjunction" which binc 